\section{Peribiliary gland damage due to liver transplantation involves peribiliary vascular plexus and vascular endothelial growth factor}

\author{
Antonio Franchitto, ${ }^{1}$ Diletta Overi, ${ }^{1}$ \\ Romina Mancinelli, ${ }^{1}$ \\ Anna Paola Mitterhofer, ${ }^{2}$ \\ Paolo Muisean, ${ }^{3}$ Francesca Tinti, ${ }^{2}$ \\ Ilaria Umbro, ${ }^{2}$ Stefan G. Hübscher, ${ }^{4,5}$ \\ Paolo Onori, ${ }^{1}$ Eugenio Gaudio, ${ }^{1}$ \\ Guido Carpino ${ }^{6}$ \\ 'Department of Anatomical, \\ Histological, Forensic Medicine and \\ Orthopedics Sciences, Sapienza \\ University of Rome, Italy \\ ${ }^{2}$ Department of Translational and \\ Precision Medicine, Sapienza University \\ of Rome, Italy \\ ${ }^{3}$ Liver Unit, University Hospitals \\ Birmingham NHS Foundation Trust, UK \\ ${ }^{4}$ Institute of Immunology and \\ Immunotherapy, University of \\ Birmingham, UK \\ ${ }^{5}$ Department of Cellular Pathology, Queen \\ Elizabeth Hospital, Birmingham, UK \\ ${ }^{6}$ Department of Movement, Human and \\ Health Sciences, Division of Health \\ Sciences, University of Rome \\ "Foro Italico", Italy
}

\begin{abstract}
Extrahepatic bile ducts are characterized by the presence of peribiliary glands (PBGs), which represent stem cell niches implicated in biliary regeneration. Orthotopic liver transplantation may be complicated by non-anastomotic strictures (NAS) of the bile ducts, which have been associated with ischemic injury of PBGs and occur more frequently in livers obtained from donors after circulatory death than in those from brain-dead donors. The aims of the present study were to investigate the PBG phenotype in bile ducts after transplantation, the integrity of the peribiliary vascular plexus (PVP) around PBGs, and the expression of vascular endothelial growth factor-A (VEGF-A) by PBGs. Transplanted ducts obtained from patients who underwent liver transplantation were studied $(\mathrm{N}=62)$. Controls included explanted bile duct samples not used for transplantation $(\mathrm{N}=10)$ with normal histology. Samples were processed for histology, immunohistochemistry and immunofluorescence. Surface epithelium is severely
\end{abstract}

injured in transplanted ducts; PBGs are diffusely damaged, particularly in ducts obtained from circulatory-dead compared to brain-dead donors. PVP is reduced in transplanted compared to controls. PBGs in transplanted ducts contain more numerous progenitor and proliferating cells compared to controls, show higher positivity for VEGF-A compared to controls, and express VEGF receptor-2. In conclusion, PBGs and associated PVP are damaged in transplanted extrahepatic bile ducts; however, an activation of the PBG niche takes place and is characterized by proliferation and VEGF-A expression. This response could have a relevant role in reconstituting biliary epithelium and vascular plexus and could be implicated in the genesis of non-anastomotic strictures.

\section{Introduction}

Large intrahepatic and extrahepatic bile ducts are characterized by the presence of peribiliary glands (PBGs), which are located within the bile duct wall and have been shown to harbor a heterogeneous population of stem cells, the biliary tree stem/progenitor cells (BTSCs). ${ }^{1}$ Their stem cell properties, including self-replication and capability to differentiate into mature cells, have been characterized. ${ }^{1}$

BTSCs and PBGs have been identified as key players in the pathogenesis of human cholangiopathies. 2,3 Hyperplasia of peribiliary glands has been associated with the development of fibrosis in large bile ducts in patients with primary sclerosing cholangitis. ${ }^{2}$ Damage to PBGs has been implicated in the development of nonanastomotic strictures (NAS) of the biliary tree, a complication emerging after orthotopic liver transplantation (OLT) and potentially leading to re-transplantation. ${ }^{4}$ Interestingly, livers obtained from donors after circulatory death (DCD) are more likely to develop NAS compared to those obtained from brain-dead donors (DBD). ${ }^{5,6}$ The transplanted extrahepatic biliary tree experiences ischemia-reperfusion injury, which could be important in the pathogenesis of PBG damage. ${ }^{4}$

Ischemia-reperfusion injury is associated with activation of signalling pathways involving hypoxia-inducible factor 1 (HIF1) and vascular endothelial growth factor (VEGF). ${ }^{7}$ The VEGF family includes signalling proteins which act on endothelial cell proliferation and vessel pathophysiology. ${ }^{8}$ Interestingly, several epithelial cells have been shown to express VEGF pathway elements, which take part in the modulation of cell growth in both autocrine and paracrine manner. ${ }^{9}$ However, little is
Correspondence: Prof. Guido Carpino, Department of Movement, Human and Health Sciences, Division of Health Sciences, University of Rome "Foro Italico", Piazza Lauro De Bosis 6, 00135 Rome, Italy. Tel./Fax: +39.06.36733.202

E-mail: guido.carpino@uniroma1.it

Keywords: Stem cells; bile duct; liver transplantation; biliary tract disease; HypoxiaInducible Factor 1 alpha.

Contributions: AF, GC, concept and design, experiments, data analysis and interpretation, writing of the manuscript; DO, IU, FT, data analysis and interpretation, experiments, writing of the manuscript, final approval; SGH, APM, RM, PM, acquisition of data, editing and final approval of the manuscript; PO, EG, concept and design, data interpretation, study supervision, funding acquisition.

Conflict of interest: The authors declare no conflict of interest.

Funding: The study was supported by research project grant from Sapienza University of Rome (EG, PO) and by a sponsored research agreement (SRAs) from Vesta Therapeutics (Bethesda, MD, USA). The study was further supported by a research project grant from the European Society for Organ Transplantation.

Received for publication: 7 March 2019. Accepted for publication: 24 April 2019.

This work is licensed under a Creative Commons Attribution-NonCommercial 4.0 International License (CC BY-NC 4.0).

${ }^{\circ}$ Copyright: the Author(s), 2019

Licensee PAGEPress, Italy

European Journal of Histochemistry 2019; 63:3022 doi:10.4081/ejh.2019.3022

known about the role of VEGFs in BTSC regeneration.

In the light of these observations, the aims of the present study were to investigate in transplanted bile ducts obtained from DBDs and DCDs: i) changes in PBG mass and morphology; ii) phenotypic changes in cells within PBGs; iii) integrity of the peribiliary vascular plexus (PVP); and, iv) expression of VEGF family members by PBGs.

\section{Materials and Methods}

\section{Recipient, donor and surgical characteristics}

This is a retrospective single-centre study of 62 patients who underwent liver transplantation (34 from DBD and 28 from 
DCD donors) at Queen Elizabeth Hospital Birmingham/University Hospitals Birmingham (UHB) National Health Service (NHS) Foundation Trust from July 2012 to March 2015, with a minimum follow-up of 12 months.

Baseline recipient characteristics were extracted from the hospital administrative databases at the time of admission; baseline bloods were extracted based on the last measurement before transplantation. Functional donor warm ischemia time is exclusively related to DCD donors and was defined as the time from the decline of patient's systolic arterial pressure below 50 $\mathrm{mm} \mathrm{Hg}$ and/or arterial oxygen saturation below $70 \%$, to cold perfusion. It includes the mandatory 5-min period of waiting, after asystole, before donor incision. Graft cold ischemia time was defined as the time from the cold perfusion to the liver out of ice before the implantation in the recipient. Recipient warm ischemia time was defined as the time from liver out of ice to hepatic artery reperfusion into the recipient.

The project was approved by University Hospitals Birmingham NHS Foundation Trust's Liver Research Forum (prot. C26A14N8L4) and by the Human Biomaterials Resource Centre, College Medical \& Dental Sciences, University of Birmingham (Application Number: 14196). Written informed consent was obtained from each patient and the study protocol was conformed to the Ethical Guidelines of the 1975 Declaration of Helsinki.

\section{Histological assessments}

The samples of transplanted extrahepatic bile ducts obtained from DBD $(n=34)$ or DCD $(n=28)$ donors were retrieved at the time of transplantation after portal and arterial reperfusion of the liver and before starting the biliary anastomosis. Samples were immediately preserved in $10 \%$ formaldehyde for 1-3 $\mathrm{h}$ and embedded in paraffin by a dedicated team of researchers to avoid delay between sample collection and fixation/storage. Routine histological stains including using hematoxylin-eosin (H\&E) and Periodic acid-Schiff (PAS) were performed. Control samples included bile duct samples from DBD livers not used for transplantation $(n=10)$. These samples were obtained at the moment of the organ explant, thus not experiencing any ischemia and serving as healthy controls. The walls of these ducts included PBGs characterized by almost normal histological appearances, as previously described. ${ }^{1}$

The histological evaluation of bile duct injury was carried out using $H \& E$ stained sections of paraffin-embedded tissue sam- ples. The degree of injury was graded using a scoring system as described in two previous studies ${ }^{4,10}$ (Supplementary Table 1). Moreover, severely damaged PBGs were identified as glandular acini displaying disrupted and detached epithelium and/or cells with pyknotic nuclei and distorted shape and are expressed as percentage of damaged PBGs over total PBGs per bile duct. The evaluation was performed on $\mathrm{H} \& \mathrm{E}$ and/or on slides processed for cytokeratin 7 immunohistochemistry (see below).

\section{Immunohistochemistry and immunofluorescence}

From each specimen, $3-\mu \mathrm{m}$ sections were obtained. For immunohistochemistry, endogenous peroxidase activity was blocked by a $30-\mathrm{min}$ incubation in methanolic hydrogen peroxide $(2.5 \%)$. Antigens were retrieved, as indicated by the vendor, by applying Proteinase $\mathrm{K}$ (Dako, Glostrup, Denmark; code S3020) for $10 \mathrm{~min}$ at room temperature. Sections were then incubated overnight at $4{ }^{\circ} \mathrm{C}$ with primary antibodies (Supplementary Table $2)$. Then, samples were rinsed twice with phosphate buffered saline (PBS) for $5 \mathrm{~min}$, incubated for $20 \mathrm{~min}$ at room temperature with secondary biotinylated antibody, and then with Streptavidin-horseradish peroxidase (LSAB+, Dako; code K0690). Diaminobenzidine (Dako; code K3468) was used as substrate, and sections were counterstained with hematoxylin. ${ }^{11}$ Apoptosis was detected by Terminal deoxynucleotidyl transferase dUTP nick end labeling (TUNEL) assay as indicated by the vendor (ApopTag ${ }^{\circledR}$ Plus Peroxidase In situ Apoptosis Detection Kit, Chemicon International, Sigma-Aldrich, St. Louis, MI, USA; Code: S7101). For all immunoreactions, negative controls (the primary antibody was replaced with preimmune serum) were also included. Slides were scanned by a digital scanner (Aperio Scanscope CS System, Aperio Digital Pathology, Leica Biosystems, Milan, Italy) and processed by ImageScope. ${ }^{12}$ Cytokeratin 7 was used as PBG marker based on our previous studies and the area occupied by cytokeratin $7^{+}$PBGs was quantified using an image analysis algorithm and is expressed as percentage of the total bile duct wall area. ${ }^{13}$ The expression of proliferation index in PBGs was calculated by immunohistochemistry for PCNA (proliferating cell nuclear antigen). Positive nuclei were automatically counted by an image analysis software (Aperio ImageScope System) and are expressed as percentage of positive cells within PBGs. The distribution of peribiliary vascular plexus (PVP) was evaluated on CD31- stained slides and expressed as number of vessels per high-powered field (HPF) and as proportion of vessels per $\mathrm{PBG}$ (PVP/PBG ratio). ${ }^{14}$ For PAS and for immunohistochemistry for Sox9 (sexdetermining region Y-box 9, a progenitor cell marker), VEGF, and HIF-1 $\alpha$, the proportion of positive cells was automatically counted by an image analysis software (Aperio ImageScope System), then, a semi-quantitative (SQ) scoring system was applied $(0=<5 \% ; 1=5-10 \% ; 2=11-30 \%$; $3=31-50 \% ; 4=>50 \%) .{ }^{11}$

\section{Statistical analysis}

Data are expressed as mean \pm standard deviation. The Mann-Whitney U test was used to determine differences between groups. The Spearman nonparametric correlation were used. A P-value $<0.05$ was considered statistically significant. Analyses were performed using IBM SPSS software (IBM, Armonk, NY, USA).

\section{Results \\ Histological assessment of extrahepatic bile ducts}

Transplanted extrahepatic bile ducts showed variably higher degree of surface epithelial cell loss (Figure 1A, yellow arrows), mural stroma necrosis, intramural bleeding, arteriolonecrosis, and inflammation compared to controls (Table 1). Interestingly, no differences in histopathological damage was observed when ducts obtained from DBD were compared with those from DCD (Table 2) except for the detachment/loss of cells in periluminal PBG $(\mathrm{P}=0.022)$ and signs of peribiliary vascular plexus damage $(\mathrm{P}=0.043)$.

\section{Assessment of peribiliary gland damage and mass in extra-hepatic bile ducts}

The percentage of damaged PBGs was higher in transplanted $(31.4 \pm 12.8 \%)$ compared to control ducts $(4.7 \pm 3.1 \% ; \mathrm{P}<0.001$, Figure 1B). No differences in term of PAS positivity were detected between control and transplanted ducts (Figure 1C). However, the evaluation of PBG mass, conducted on cytokeratin 7-stained slides, indicated that transplanted extrahepatic bile ducts showed no difference in terms of PBG mass $(1.61 \pm 0.91 \%)$ compared to control ducts $(1.76 \pm 0.49 \% ; \mathrm{P}=0.635$; Figure 2). In transplanted ducts, $P B G$ mass inversely correlated with damaged glands $(r=0.478 ; \mathrm{P}=0.045)$. According to the increased number of damaged PBGs, the study of apoptosis by TUNEL assay indicated that transplanted ducts showed 
A

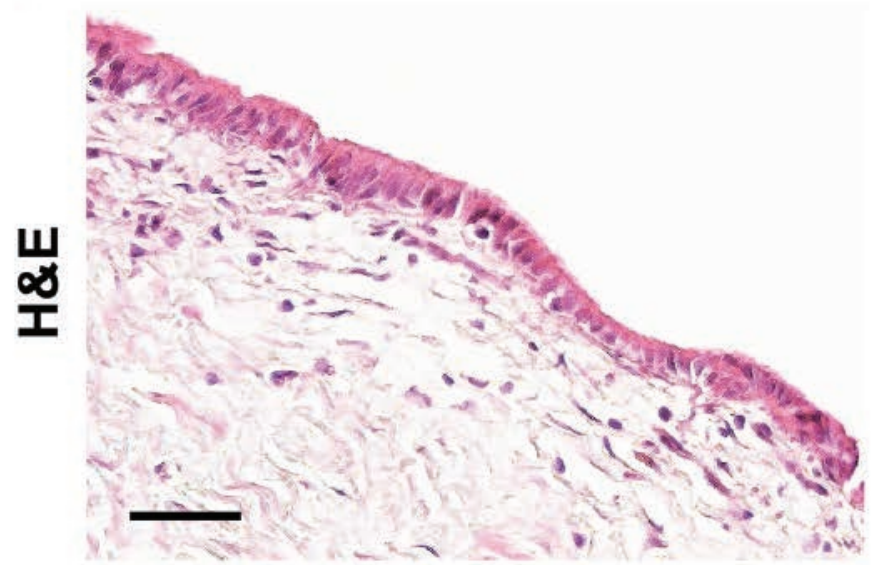

B

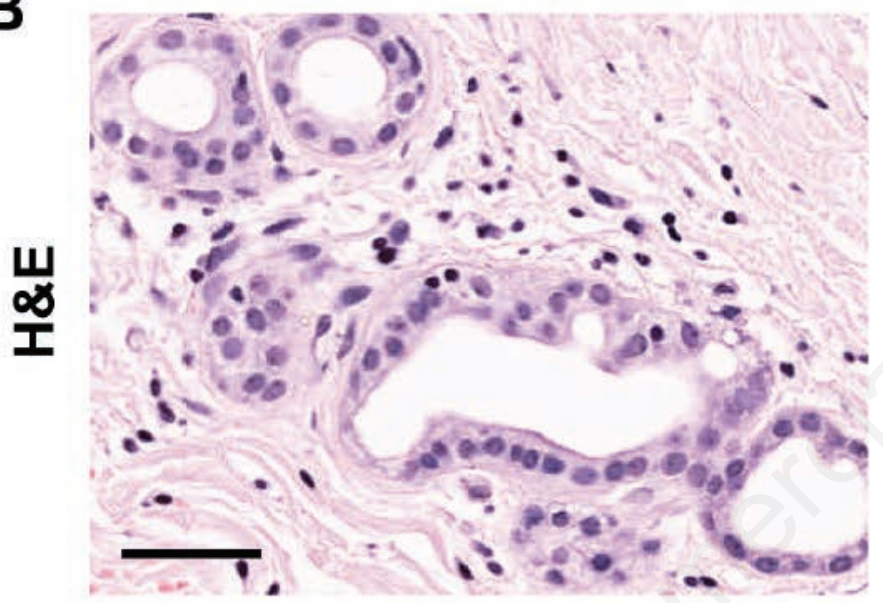

C

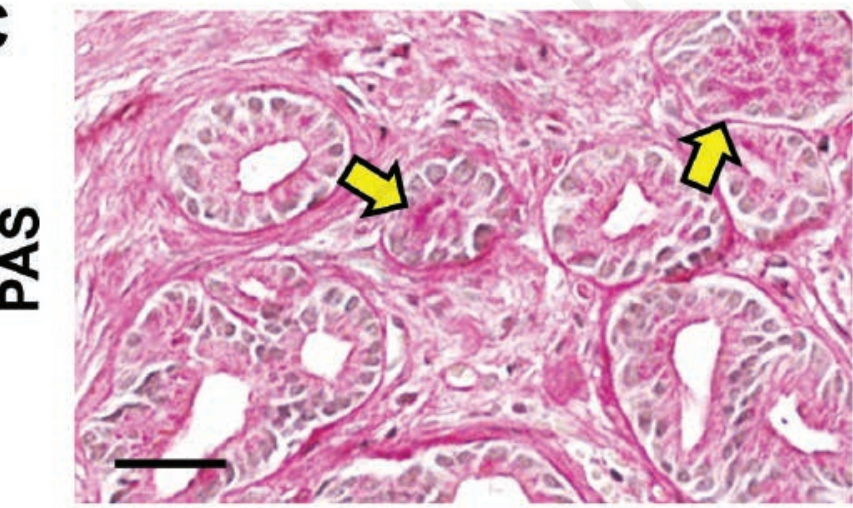

\section{TRANSPLANTED}
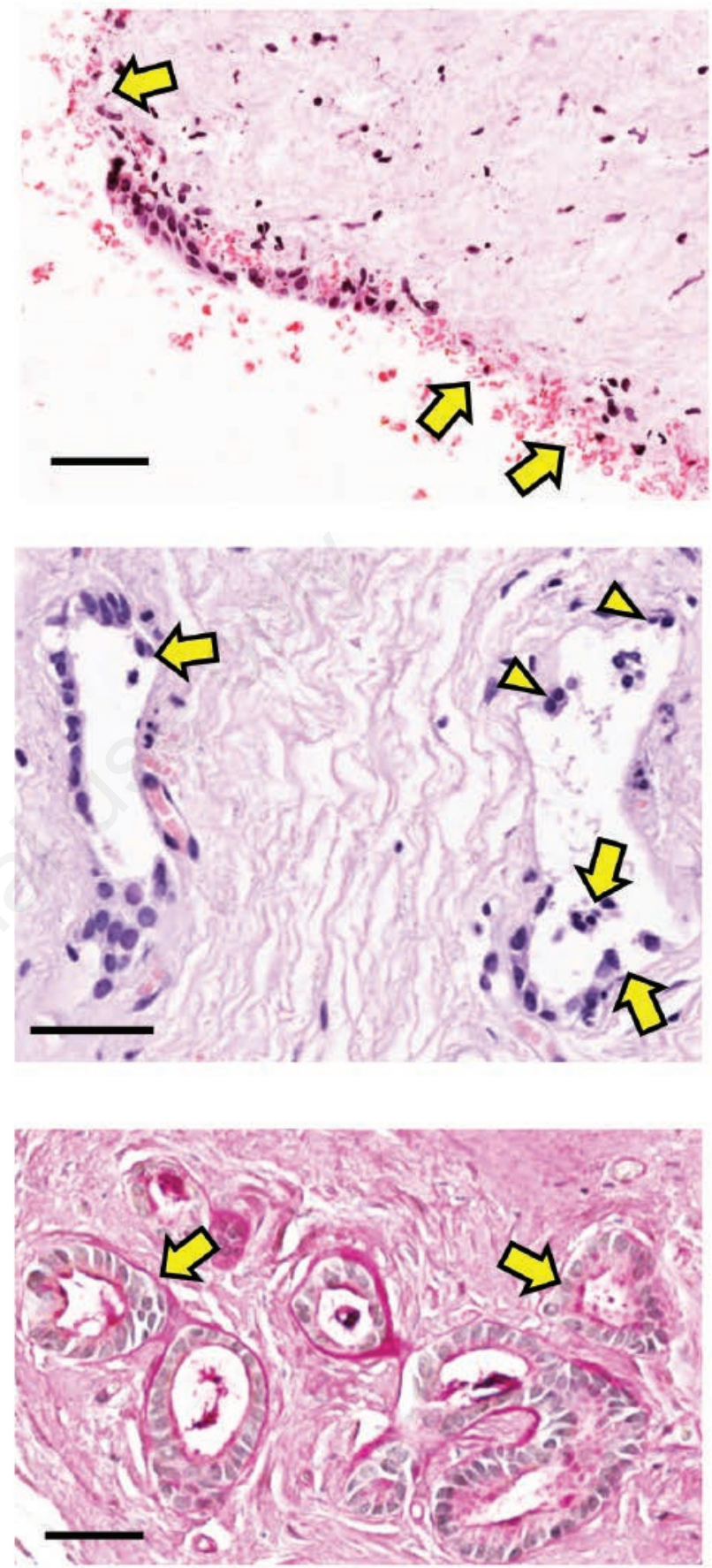

Figure 1. Histological findings and changes in peribiliary gland (PBG) mass in extrahepatic bile ducts (EHBDs). A) Haematoxylin and eosin (H\&E) stain in EHBDs obtained from control and transplanted organs; transplanted bile ducts are characterized by extensive surface epithelium loss compared to controls (arrows). B) Haematoxylin and eosin (H\&E) stain in EHBDs obtained from control and transplanted organs; transplanted EHBDs are characterized by disrupted PBG acini; damaged PBG are characterized by distorted and detached cells (arrows) and cells with pyknotic nuclei (arrowheads). C) Periodic acid-Schiff (PAS) in EHBDs obtained from control and transplanted organs; no differences in term of PAS positivity in PBGs (arrows) are detected between control and transplanted ducts. Scale bars: $50 \mu \mathrm{m}$. 
higher percentage of apoptotic PBG cells $(39.5 \pm 7.3 \%) \quad$ compared to controls (10.6 $\pm 2.7 \%$; $\mathrm{P}<0.001$; Figure 2). PBGs in transplanted extrahepatic bile ducts showed higher percentage of $\mathrm{PCNA}^{+}$and SOX $9^{+}$cells $(47.4 \pm 25.3 \%$ and SQ score: $2.7 \pm 1.2)$ compared to controls $(7.8 \pm 4.2 \%$ and SQ score: $1.3 \pm 0.5 ; \quad \mathrm{P}<0.001$ and $\mathrm{P}=0.026$, respectively; Figure 3 ). PCNA co-localized with SOX9 expression in the same cells as demonstrated by double immunofluorescence. SOX9 ${ }^{+}$PBG cells correlated with damaged PBGs in transplanted extrahepatic bile ducts $(\mathrm{r}=0.713$; $\mathrm{P}=0.031$ ).

When DBD and DCD transplanted ducts were compared, no difference was found in terms of PBG mass $(1.79 \pm 1.22 \%$ and $1.49 \pm 0.69 \%$, respectively; $\mathrm{P}=0.255$ ). However, transplanted ducts obtained from DBD showed lower percentage of damaged glands $(25.0 \pm 12.9 \%)$ compared to ducts obtained from DCD $(35.4 \pm 11.5 \%$; $\mathrm{P}=0.046$, Figure 4). DBD transplanted ducts showed lower percentage of $\mathrm{PCNA}^{+}$ cells $(50.0 \pm 17.3)$ compared with DCD (75.0 $\pm 8.6 ; \mathrm{P}=0.044$, Figure 4). No difference was revealed between DBD and DCD in terms of SOX9 expression.

\section{Peribiliary Vascular plexus and expression of vascular endothelial growth factor pathway elements in PBGs}

The evaluation of PVP was conducted on CD31 stained slides (Figure 5). Transplanted extrahepatic bile ducts showed lower number of PVP vessels per field (5.2 \pm 3.0$)$ compared to control ducts

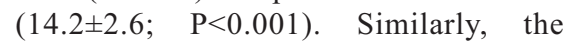
$\mathrm{PVP} / \mathrm{PBG}$ ratio was lower in transplanted bile ducts $(0.57 \pm 0.30)$ compared to controls $(1.1 \pm 0.2 ; \mathrm{P}=0.002)$. The $\mathrm{PVP} / \mathrm{PBG}$ ratio was inversely correlated with the percentage of damaged $\mathrm{PBG}$ in transplanted ducts $(r=-0.578 ; \mathrm{P}=0.039)$. No difference was found when DBD and DCD transplanted ducts were compared.

Then, the VEGF-A, VEGF-C, and HIF-1 $\alpha$ expression by PBGs was evaluated (Figure 6). VEGF-A but not VEGF-C (not shown) was expressed in PBGs. VEGF-A expression was significantly increased in transplanted extrahepatic bile ducts (SQ score: $2.3 \pm 1.1$ ) compared to controls (SQ score: $1.2 \pm 0.4 ; \mathrm{P}=0.007)$. Similarly, nuclear HIF-1 $\alpha$ expression was significantly increased in transplanted extrahepatic bile ducts (SQ score: 2.2 \pm 1.2 ) compared to controls (SQ score: $1.1 \pm 0.6 ; \mathrm{P}=0.031$ ). VEGF-A expression correlated with SOX9+ PBG cells $(r=0.686 ; \mathrm{P}=0.041)$. No difference was found when DBD and DCD transplanted ducts were compared.

Interestingly, VEGF receptor
(VEGFR)-2 was expressed by PBG cells as. demonstrated by double immunofluorescence with SOX9 (Figure 6B).

\section{Discussion}

The present study demonstrated that: i) PBGs in transplanted extrahepatic bile duct are diffusely damaged, particularly in ducts obtained from DCD compared to DBD; ii) PBGs in transplanted extrahepatic bile ducts are composed of a higher proportion of $\mathrm{SOX}^{+}$and $\mathrm{PCNA}^{+}$cells compared to controls; iii) PVP around PBGs is reduced in transplanted compared to control ducts; iv) VEGF signalling is highly activated in transplanted ducts.

PBGs are tubulo-alveolar glands located within the wall of large intrahepatic and extrahepatic bile ducts and are in direct communication with the bile duct lumen. PBGs are composed of mucinous and serous cells; ${ }^{15-17}$ moreover, PBGs contain a subpopulation (nearly $10 \%$ ) of multipotent stem cells, namely the biliary tree stem/progenitor cells (BTSCs). BTSCs can differentiate into mature cholangiocytes, hepatocytes and endocrine pancreatic cells. The stemness (i.e., self-replicative and differentiative capabilities) of BTSCs has been demonstrated both in vitro and in vivo. ${ }^{18,19}$ In murine models, BTSCs are activated in response to biliary injury. ${ }^{20,21}$ Accordingly, human chronic cholangiopathies are characterized by BTSC expansion. ${ }^{18,22}$ In primary sclerosing cholangitis, chronic inflammation induces BTSC activation, thus leading to $\mathrm{PBG}$ compartment expansion and driving fibrosis in the walls of large bile ducts; ${ }^{2}$ furthermore, PBG niche can induce the remodelling of peribiliary vascular plexus via VEGF pathway. ${ }^{14}$

Nevertheless, PBGs themselves can be affected during bile duct injury. ${ }^{23-25}$ At OLT, the biliary tree is subjected to ischemia from the time of liver explant to reperfusion in the recipient; ${ }^{4,26}$ in this context, previous reports showed that transplanted bile ducts are characterized by extensive histological injury of bile duct wall, including also PBGs. ${ }^{4}$ This injury was reduced in organs, which had undergone machine perfusion prior to transplantation, indicating how preventing ischemia can preserve bile duct and PBG integrity. ${ }^{27}$

Table 1. Histological scoring of control and transplanted extrahepatic bile ducts.

\begin{tabular}{|c|c|c|c|}
\hline & $\begin{array}{l}\text { Control ducts } \\
(\mathrm{n}=10)\end{array}$ & $\begin{array}{l}\text { Transplanted ducts } \\
\qquad(\mathrm{n}=62)\end{array}$ & P-value \\
\hline $\begin{array}{l}\text { Biliary epithelial cell loss } \\
\text { No epithelial loss } \\
\leq 50 \% \text { epithelial loss } \\
>50 \% \text { epithelial loss }\end{array}$ & $\begin{array}{l}5 / 10(50 \%) \\
4 / 10(40 \%) \\
1 / 10(10 \%)\end{array}$ & $\begin{array}{c}0 / 62(0 \%) \\
2 / 62(3.2 \%) \\
60 / 62(96.8 \%)\end{array}$ & $<0.001$ \\
\hline $\begin{array}{l}\text { Mural stroma necrosis } \\
\text { No necrosis } \\
\leq 25 \% \text { of duct wall necrotic } \\
25-50 \% \text { of duct wall necrotic } \\
>50 \% \text { of duct wall necrotic }\end{array}$ & $\begin{array}{l}10 / 10(100 \%) \\
0 / 10(0 \%) \\
0 / 10(0 \%) \\
0 / 10(0 \%)\end{array}$ & $\begin{array}{l}10 / 62(16.1 \%) \\
16 / 62(25.8 \%) \\
13 / 62(21.0 \%) \\
23 / 62(37.1 \%)\end{array}$ & $<0.001$ \\
\hline $\begin{array}{l}\text { Intramural bleeding } \\
\text { No bleeding } \\
\leq 50 \% \text { of the bile duct wall } \\
>50 \% \text { of the bile duct wall }\end{array}$ & $\begin{array}{c}10 / 10(100 \%) \\
0 / 10(0 \%) \\
0 / 10(0 \%)\end{array}$ & $\begin{array}{c}24 / 62(38.7 \%) \\
38 / 62(61.3 \%) \\
0 / 62(0 \%)\end{array}$ & $<0.001$ \\
\hline $\begin{array}{l}\text { Inflammation } \\
\text { No inflammation } \\
\text { At least one HPF with }>10 \text { leukocytes } \\
\text { At least one HPF with }>50 \text { leukocytes }\end{array}$ & $\begin{array}{c}10 / 10(100 \%) \\
0 / 10(0 \%) \\
0 / 10(0 \%)\end{array}$ & $\begin{array}{c}52 / 62(83.9 \%) \\
3 / 62(4.8 \%) \\
7 / 62(11.3 \%)\end{array}$ & $<0.001$ \\
\hline $\begin{array}{l}\text { Peribiliary vascular plexus damage } \\
\text { No injury } \\
\leq 50 \% \text { vessels damaged } \\
>50 \% \text { vessels damaged }\end{array}$ & $\begin{array}{l}9 / 10(90 \%) \\
1 / 10(10 \%) \\
0 / 10(0 \%)\end{array}$ & $\begin{array}{c}51 / 62(82.3 \%) \\
11 / 62(17.7 \%) \\
0 / 62(0 \%)\end{array}$ & NS \\
\hline $\begin{array}{l}\text { Arteriolonecrosis } \\
\text { None } \\
\leq 50 \% \text { vessels damaged } \\
>50 \% \text { vessels damaged }\end{array}$ & $\begin{array}{l}9 / 10(90 \%) \\
1 / 10(10 \%) \\
0 / 10(0 \%)\end{array}$ & $\begin{array}{c}52 / 62(83.9 \%) \\
10 / 62(16.1 \%) \\
0 / 62(0 \%)\end{array}$ & NS \\
\hline $\begin{array}{l}\text { Thrombosis } \\
\text { Absent } \\
\text { Present }\end{array}$ & $\begin{array}{l}10 / 10(100 \%) \\
0 / 10(0 \%)\end{array}$ & $\begin{array}{c}61 / 62(98.4 \%) \\
1 / 62(1.6 \%)\end{array}$ & NS \\
\hline
\end{tabular}

Statistically significant P-values are reported; HPF, high-powered field; NS, not significant. 
Recently, an ex vivo model showed that the regeneration of ischemic injured surface epithelium in explanted biliary tree is ensured by BTSC activation. ${ }^{28}$ In the present study, the response of PBG niche to bile duct injury in transplanted ducts was investigated. In our series, transplanted bile ducts were characterized by loss of surface epithelium, necrosis and inflammation. Compared to histologically normal controls, transplanted ducts did not differ in PBG mass extension but were characterized by a higher proportion of damaged PBGs. Remarkably, an increased percentage of damaged PBGs was observed in ducts obtained from DCD compared to DBD ones. This aspect is in accordance with the longer ischemic period time experienced by DCD organs. ${ }^{5}$ The degree of PBG damage during the transplant procedure is clinically relevant due to its correlation with the development of non-anastomotic biliary strictures (NAS) within the first year after OLT, which often leads to liver re-transplantation. ${ }^{4}$ When the phenotype of cells within PBGs was studied, we observed a higher proportion of cells expressing SOX9, a marker of stem/progenitor cells. ${ }^{29}$ Generally, stem/progenitor cells are characterized by higher resistance to ischemia compared to mature cells. ${ }^{30}$ In the biliary tree, mature cholangiocytes are highly susceptible to ischemic injury, ${ }^{31}$ as also confirmed by extensive loss of surface epithelium in our series. Thus, the high proportion of $\mathrm{SOX}^{+}$BTSCs within PBGs suggests that these cells are more resistant to ischemic injury compared to mature cells. In keeping with that, PBGs in transplanted ducts were composed of a higher percentage of proliferating BTSCs compared to controls; hence in transplanted ducts, BTSCs are a relatively spared cell compartment and counteract the ischemic insult by a replicative response. Moreover, we did not find differences in term of mucous cells within PBGs between transplanted and control ducts. This suggests that response to ischemic injury implies different mechanisms compared to other human diseases determining PBG activation (i.e., primary sclerosing cholangitis) and characterized by high mucinous metaplasia. $^{2}$

Besides PBGs, bile duct injury in transplanted ducts also involves vessels within duct walls. Transplanted ducts were characterized by an overall lower extent of PVP compared to controls. Most interestingly, the reduction of vessels around PBGs in transplanted duct was correlated with PBG damage. These results indicate that ischemic injury could be accentuated by the destruction of PVP around PBGs. Thus, we further evaluated the activation of VEGF pathway in transplanted bile ducts. VEGF is a family of related growth factors that includes VEGF-A, -B, -C, -D, and $-\mathrm{E}$ and placenta growth factor. ${ }^{9} \mathrm{VEGF}-$ $A$ is a mitogen for vascular endothelial cells and regulates vascular pathophysiology, including vasodilatation, vascular permeability, migration, and survival of endothelial cells. Three main receptors have been identified for VEGF (VEGFR), VEGFR-1 (Flt-1), VEGFR-2 (Flk-1), and VEGFR-3 (Flt-4). While VEGF-A interacts with VEGFR-1 and VEGFR-2, VEGF-C interacts with VEGFR-2 and

VEGFR-3. ${ }^{8}$ The expression of VEGF and its receptors is not restricted to vascular endothelial cells; VEGF is secreted by several epithelia, where it modulates cell growth by autocrine and paracrine mechanisms. Particularly, it has been shown that in experimental models of biliary tree regeneration, cholangiocytes can secrete VEGFs and express VEGFR-2 and VEGFR-3; $9,31,32$ in turn, VEGF can induce cholangiocyte proliferation and mediate the adaptive proliferative response of cholangiocytes to cholestasis. Moreover, VEGF-A secreted by proliferating cholan-

Table 2. Histomorphological evaluation of extrahepatic bile ducts in donors after circulatory death (DCD) vs brain-dead donor (DBD) organ recipients.

\begin{tabular}{|c|c|c|c|}
\hline & DCD $(28 / 62)$ & DBD $(34 / 62)$ & P-value \\
\hline $\begin{array}{l}\text { Biliary epithelial cell loss } \\
\text { No epithelial loss } \\
\leq 50 \% \text { epithelial loss } \\
>50 \% \text { epithelial loss }\end{array}$ & $\begin{array}{c}0 / 28(0 \%) \\
0 / 28(0 \%) \\
28 / 28(100 \%)\end{array}$ & $\begin{array}{c}0 / 34(0 \%) \\
2 / 34(5.9 \%) \\
32 / 34(94.1 \%)\end{array}$ & NS \\
\hline $\begin{array}{l}\text { Mural stroma necrosis } \\
\text { No necrosis } \\
\text { Duct wall necrotic } \\
\leq 25 \% \text { of duct wall necrotic } \\
25-50 \% \text { of duct wall necrotic } \\
>50 \% \text { of duct wall necrotic }\end{array}$ & $\begin{array}{c}3 / 28(10.7 \%) \\
25 / 28(89.3 \%) \\
7 / 28(25 \%) \\
4 / 28(14.3 \%) \\
14 / 28(50 \%)\end{array}$ & $\begin{array}{l}7 / 34(20.5 \%) \\
27 / 34(79 \%) \\
9 / 34(26.5 \%) \\
9 / 34(26.5 \%) \\
9 / 34(26.5 \%)\end{array}$ & NS \\
\hline $\begin{array}{l}\text { Intramural bleeding } \\
\text { No bleeding } \\
\leq 50 \% \text { of the bile duct wall } \\
>50 \% \text { of the bile duct wall }\end{array}$ & $\begin{array}{c}10 / 28(35.7 \%) \\
18 / 28(64.3 \%) \\
0 / 28(0 \%)\end{array}$ & $\begin{array}{c}14 / 34(41.2 \%) \\
20 / 34(58.8 \%) \\
0 / 34(0 \%)\end{array}$ & NS \\
\hline $\begin{array}{l}\text { Inflammation } \\
\text { No inflammation } \\
\text { At least one HPF with }>10 \text { leukocytes } \\
\text { At least one HPF with }>50 \text { leukocytes }\end{array}$ & $\begin{array}{c}25 / 28(89.3 \%) \\
1 / 28(4.8 \%) \\
2 / 28(7.1 \%)\end{array}$ & $\begin{array}{c}27 / 34(79.4 \%) \\
2 / 34(5.9 \%) \\
5 / 34(14.7 \%)\end{array}$ & NS \\
\hline $\begin{array}{l}\text { Peribiliary vascular plexus damage } \\
\text { No injury } \\
\leq 50 \% \text { vessels damaged } \\
>50 \% \text { vessels damaged }\end{array}$ & $\begin{array}{c}20 / 28(71.4 \%) \\
8 / 28(28.6 \%) \\
0 / 28(0 \%)\end{array}$ & $\begin{array}{c}31 / 34(91 \%) \\
3 / 34(8.8 \%) \\
0 / 34(0 \%)\end{array}$ & 0.043 \\
\hline $\begin{array}{l}\text { Arteriolonecrosis } \\
\quad \text { None } \\
\quad \leq 50 \% \text { vessels damaged } \\
>50 \% \text { vessels damaged }\end{array}$ & $\begin{array}{c}22 / 28(78.6 \%) \\
6 / 28(21.4 \%) \\
0 / 28(0 \%)\end{array}$ & $\begin{array}{c}30 / 34(88.2 \%) \\
4 / 34(11.8 \%) \\
0 / 34(0 \%)\end{array}$ & NS \\
\hline $\begin{array}{l}\text { Thrombosis } \\
\text { Absent } \\
\text { Present }\end{array}$ & $\begin{array}{c}27 / 28(96.4 \%) \\
1 / 28(3.6 \%)\end{array}$ & $\begin{array}{c}34 / 34(100 \%) \\
0 / 34(0 \%)\end{array}$ & NS \\
\hline $\begin{array}{l}\text { Periluminal peri-biliary gland damage } \\
\text { No signs of injury } \\
\text { Detachment/loss of cells } \\
\leq 50 \% \text { detachment/loss of cells } \\
>50 \% \text { detachment/loss of cells } \\
\text { Not available }\end{array}$ & $\begin{array}{c}7 / 28(25 \%) \\
20 / 28(75 \%) \\
17 / 28(60.7 \%) \\
3 / 28(10.7 \%) \\
1 / 28(3.6 \%)\end{array}$ & $\begin{array}{c}19 / 34(55.9 \%) \\
14 / 34(44.1 \%) \\
11 / 34(32.4 \%) \\
3 / 34(8.8 \%) \\
1 / 34(2.9 \%)\end{array}$ & $\begin{array}{l}\text { NS } \\
0.022\end{array}$ \\
\hline $\begin{array}{l}\text { Deep peri-biliary gland damage } \\
\text { No signs of injury } \\
\text { Loss of cells } \\
\leq 50 \% \text { loss of cells } \\
>50 \% \text { loss of cells } \\
\text { Not available }\end{array}$ & $\begin{array}{c}13 / 28(46.4 \%) \\
15 / 28(53.6 \%) \\
13 / 28(46.4 \%) \\
2 / 28(7.2 \%) \\
0 / 28(0 \%)\end{array}$ & $\begin{array}{c}18 / 34(53.0 \%) \\
15 / 34(47 \%) \\
13 / 34(38.2 \%) \\
2 / 34(5.9 \%) \\
1 / 34(2.9 \%)\end{array}$ & NS \\
\hline
\end{tabular}

Statistically significant P-values are reported; HPF, high-powered field; NS, not significant. 
giocytes in response to damage can induce PVP remodeling. 9,33,34 Similarly, hepatic progenitor cells are activated in human chronic pathologies ${ }^{35}$ and can secrete VEGFs and drive neo-angiogenesis within their niche. ${ }^{36}$ In the present study, we demonstrated that PBGs can produce VEGF-A but not VEGF-C in response to ischemic injury in extrahepatic bile ducts; this could be interpreted as a putative response to PVP impairment. In keeping, VEGF-C is a key driver of lymphangiogenesis, ${ }^{37}$ thus its expression could be not stimulated in PBGs by ischemic condition experienced by transplanted ducts. In par-
A

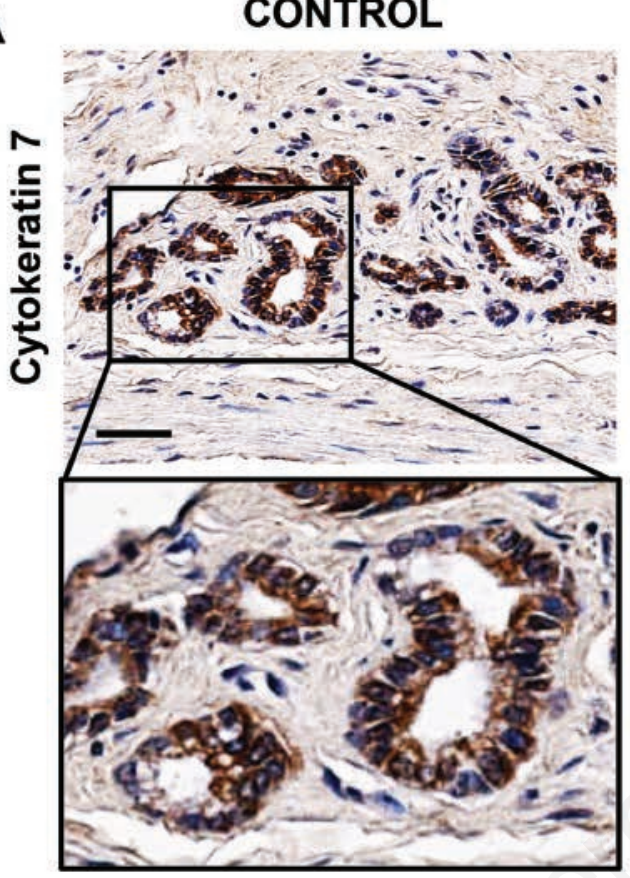

B
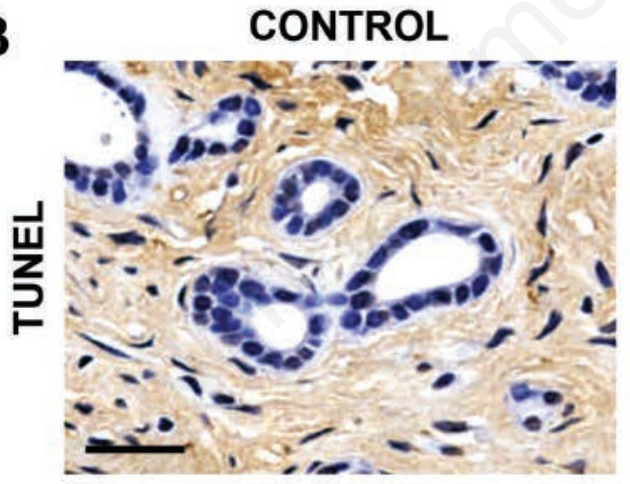

TRANSPLANTED

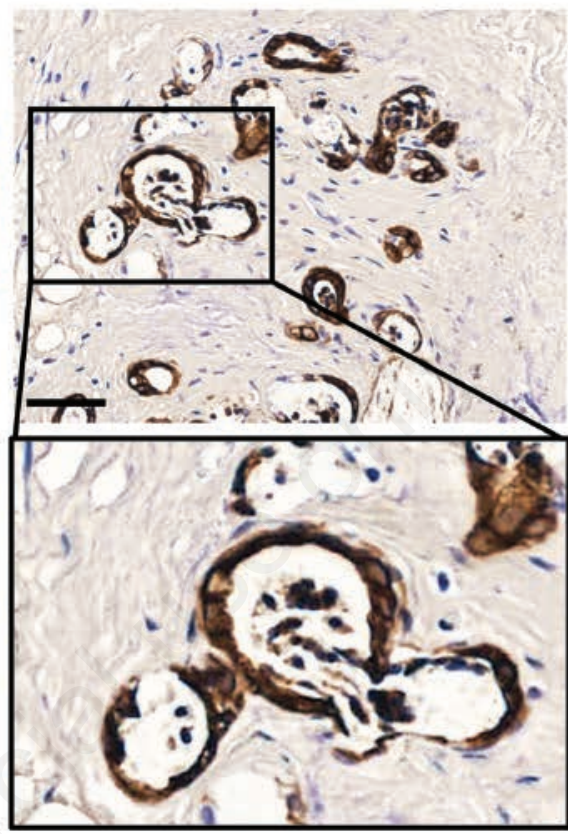

TRANSPLANTED

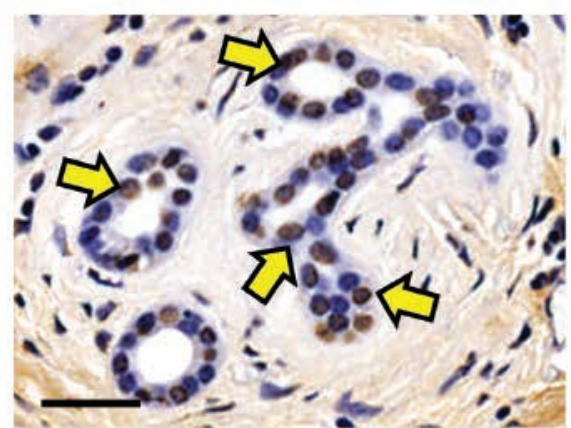

C
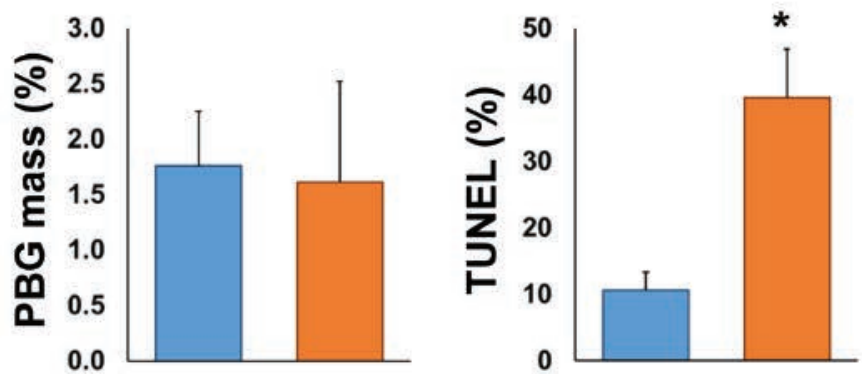

\section{$\square$ Transplanted}

Figure 2. Peribiliary gland (PBG) mass in extra-hepatic bile ducts (EHBDs). A) Immunohistochemistry for cytokeratin 7 in EHBDs obtained from control and transplanted organs; transplanted EHBDs display a similar PBG mass compared to controls; area in the box is magnified in the panels below; scale bars: $50 \mu \mathrm{m}$. B) Terminal deoxynucleotidyl transferase dUTP nick end labelling (TUNEL) assay in EHBDs obtained from control and transplanted organs; transplanted EHBDs display higher TUNEL expression in PBGs compared to controls; scale bars: $50 \mu \mathrm{m}$. C) Histogram shows means and standard deviation of PBG mass and TUNEL expression in control and transplanted ducts; ${ }^{*} \mathbf{P}<0.05$ compared to controls. 
allel with VEGF-A expression, we observed a higher percentage of HIF- $1 \alpha$ positive PBGs in transplanted bile ducts compared to controls; this in accordance with previous evidence that VEGF-A secretion by epithelial cell is induced via a HIF-mediated pathway in response to ischemia. ${ }^{7,38}$ Interestingly, PBGs in transplanted bile ducts were positive for VEGFR-2, suggesting that VEGF-A could also have a paracrine/autocrine effect on BTSCs. In conclusion, this study confirms that the PBG compartment is damaged in transplanted ducts during OLT procedures; however, PBG integrity could play a rele-
A

늠

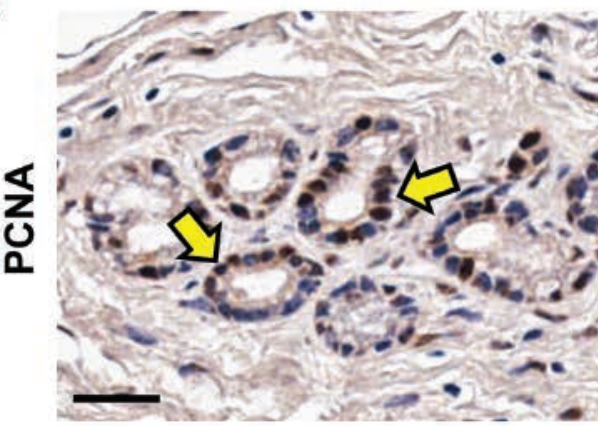

CONTROL

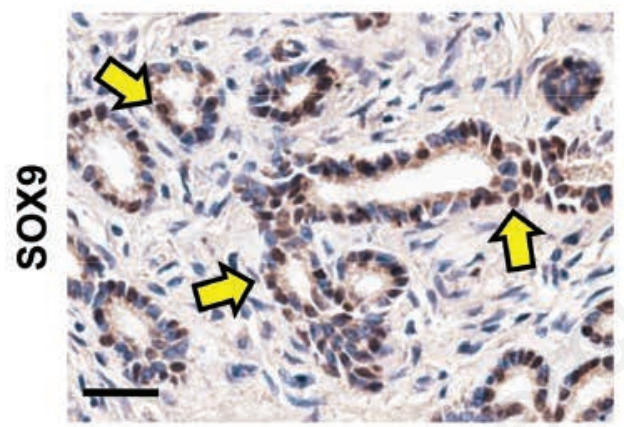

TRANSPLANTED
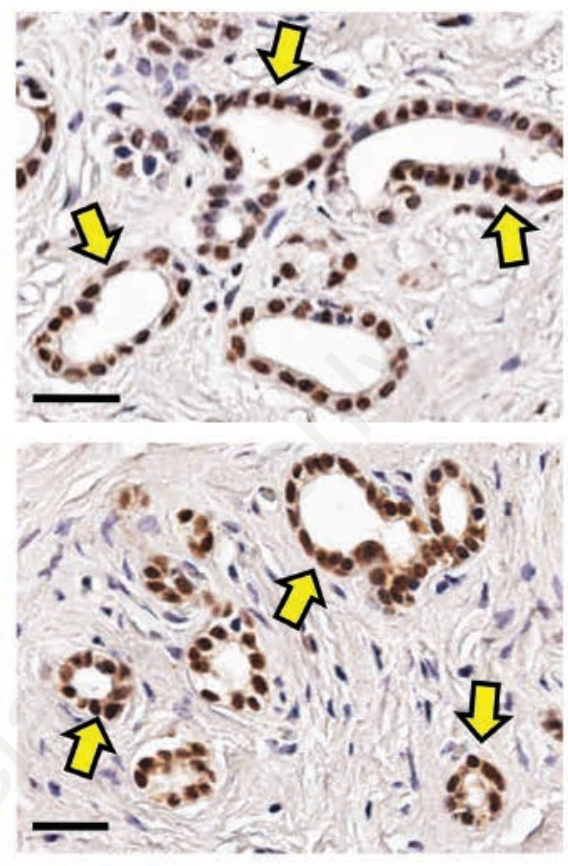

B
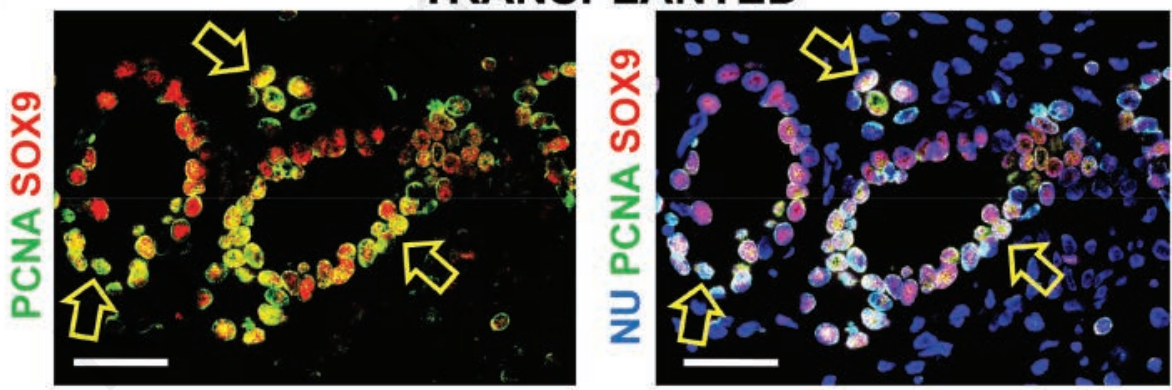

C
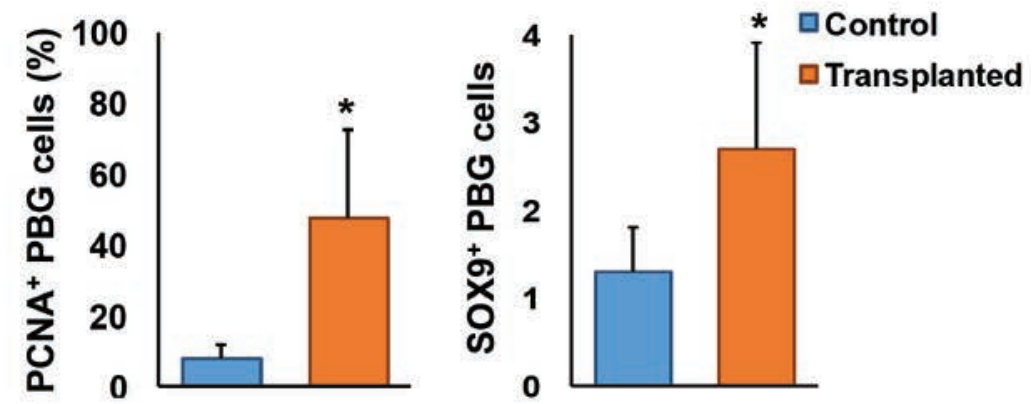

Figure 3. Peribiliary gland (PBG) cell proliferation and stem cell marker expression in extra-hepatic bile ducts (EHBDs). A) Immunohistochemistry for proliferating cell nuclear antigen (PCNA) and sex-determining region Y-box 9 (SOX9) in EHBDs obtained from control and transplanted organs; transplanted bile ducts are characterized by a higher percentage of proliferating (PCNA+) PBG cells (upper panels) and SOX9+ PBG cells (lower panels) compared to controls (arrows); scale bars: 25 um. B) Immunofluorescence for PCNA (green) and SOX9 (red) in transplanted EHBDs; PCNA expression co-localizes with SOX9 expression in PBG cells (yellow arrows); in the panel on the right, nuclei are displayed in blue; scale bars: $25 \mu \mathrm{m}$. C) Histograms show means and standard deviation of the percentage of PCNA+ and SOX9+ PBG cells; ${ }^{*} \mathrm{P}<0.05$. 
vant role in reconstituting biliary surface epithelium and PVP after ischemic injury by means of VEGF-A expression, thus implicating the presence of an interplay that could be necessary for appropriate biliary restoration after OLT procedure. Clinically, these aspects are particularly relevant since they could be implicated in the pathogenesis of NAS in transplanted livers, which often leads to liver re-transplantation.
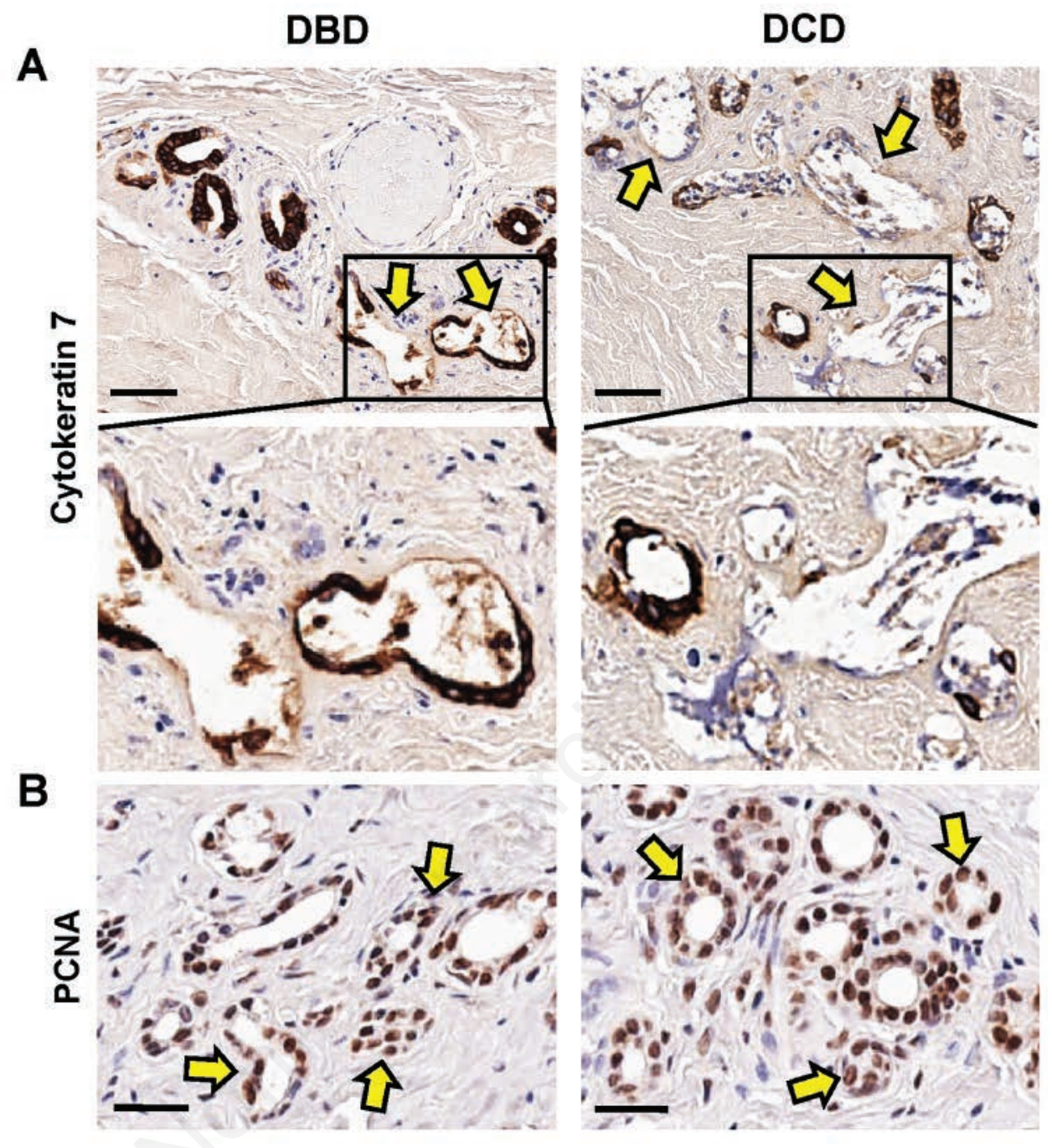

C

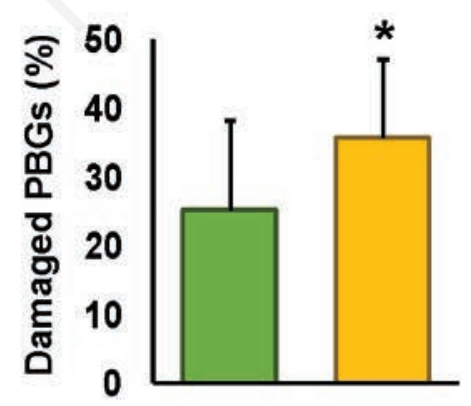

口DBD पDCD

Figure 4. Peribiliary gland (PBG) injury and cell proliferation in extra-hepatic bile ducts (EHBDs). A) Immunohistochemistry for cytokeratin 7 in transplanted EHBDs obtained from brain-dead donors (DBD) and donors after circulatory death (DCD); DCD ducts are characterized by higher percentage of damaged PBGs compared to DBD ones (arrows); area in the boxes are magnified in the panels below; scale bars: $50 \mu \mathrm{m}$. B) Immunohistochemistry for proliferating cell nuclear antigen (PCNA) in EHBDs obtained from DBD and DCD; PBGs in DCD ducts are characterized by a higher number of proliferating (PCNA+) cells compared to DBD ducts (arrows); scale bars: $25 \mu \mathrm{m}$. C) Histograms show means and standard deviation of the percentage of damaged PBGs and PCNA+ PBG cells; $* \mathbf{P}<\mathbf{0 . 0 5}$. 
A

CONTROL

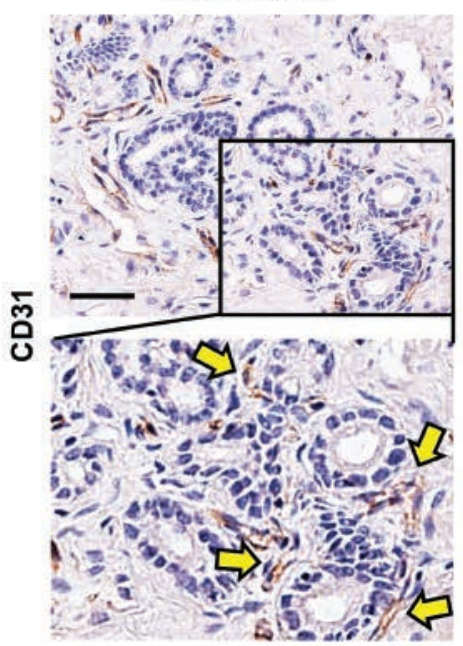

\section{TRANSPLANTED}

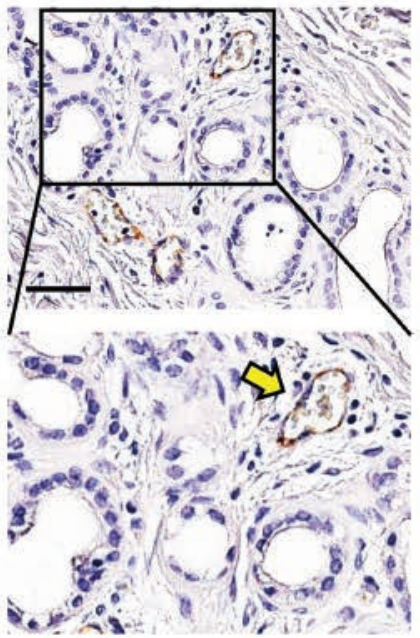

B
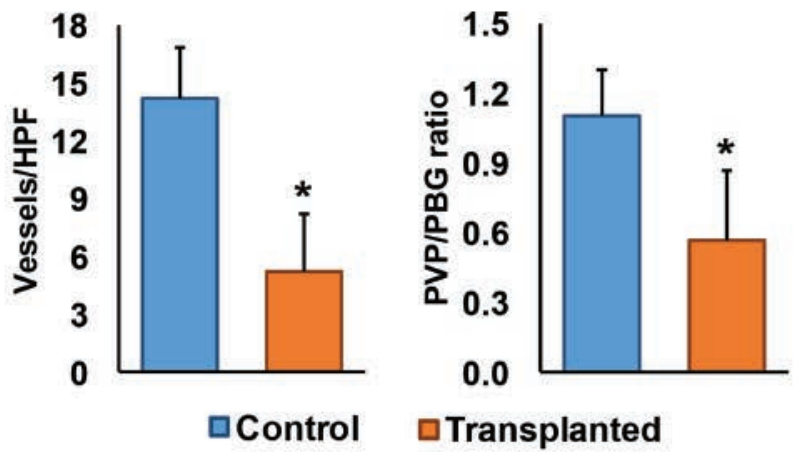

Figure 5. Peribiliary vascular plexus (PVP) and relationship with peribiliary glands (PBGs) in extrahepatic bile ducts (EHBDs). A) Immunohistochemistry for CD31 in EHBDs obtained from control and transplanted organs; transplanted EHBDs are characterized by lower extent of PVP compared to control (arrows); area in the boxes are magnified in the panels below; scale bars: $100 \mathrm{um}$. B) Histograms show means

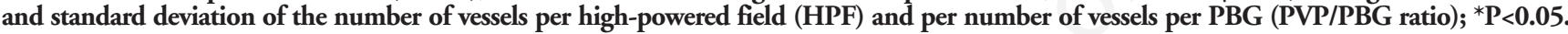

A
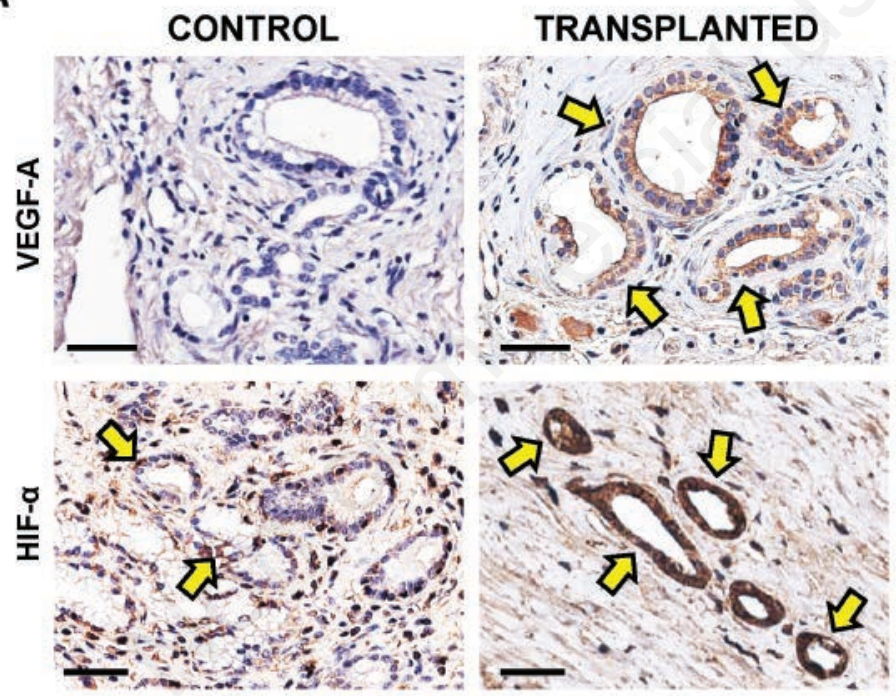

B
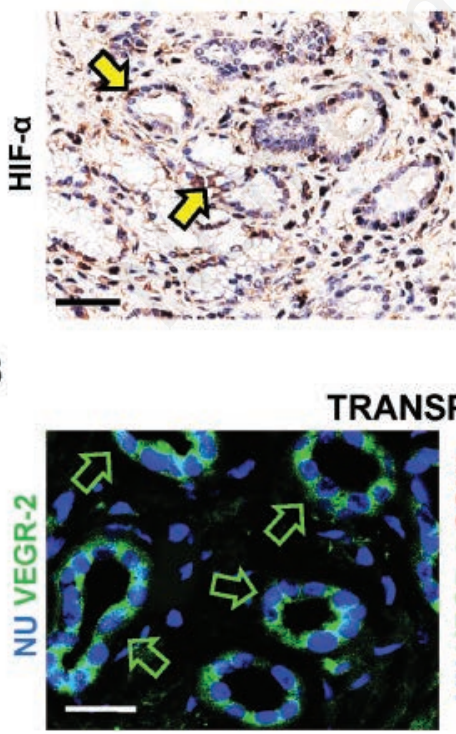

TRANSPLANTED

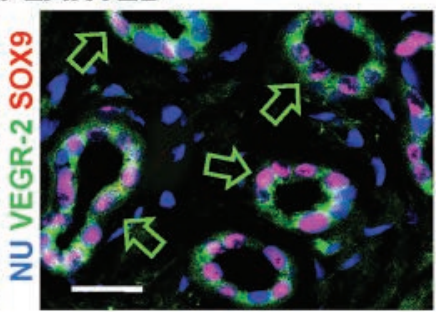

C
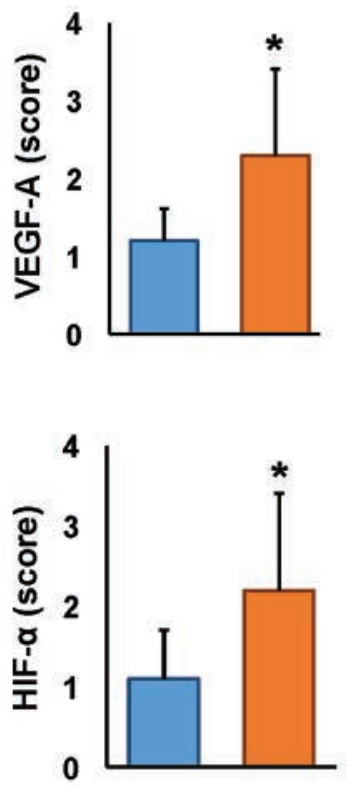

口Control

uTransplanted

Figure 6. Peribiliary gland (PBG) phenotype in extrahepatic bile ducts (EHBDs). A) Immunohistochemistry for vascular endothelial growth factor (VEGF)-A and hypoxia-inducible factor (HIF)- $\alpha$ in EHBDs obtained from control and transplanted organs; PBG cells in transplanted EHBDs display increased expression of VEGF-A (upper panels) and HIF- $\alpha$ (lower panels) compared to controls (arrows); scale bars: $50 \mu \mathrm{m}$. B) Immunofluorescence for VEGF receptor (VEGFR)-2 (green) and sex-determining region Y-box 9 (SOX9, red) in transplanted EHBDs; PBG cells (SOX9+) are characterized by the expression of VEGFR-2 (green arrows); separate channels are provided; nuclei are displayed in blue; scale bars: $25 \mu \mathrm{m}$. C) Histograms show means and standard deviations of positivity score for VEGF-A and HIF- $\alpha ;{ }^{*} \mathbf{P}<0.05$. 


\section{References}

1. Cardinale V, Wang Y, Carpino G, Cui CB, Gatto M, Rossi M, et al. Multipotent stem/progenitor cells in human biliary tree give rise to hepatocytes, cholangiocytes, and pancreatic islets. Hepatology 2011;54:2159-72.

2. Carpino G, Cardinale V, Renzi A, Hov JR, Berloco PB, Rossi $M$, et al. Activation of biliary tree stem cells within peribiliary glands in primary sclerosing cholangitis. J Hepatol 2015;63: 1220-8.

3. Igarashi S, Sato Y, Ren XS, Harada K, Sasaki M, Nakanuma Y. Participation of peribiliary glands in biliary tract pathophysiologies. World J Hepatol 2013;5: 425-32.

4. op den Dries S, Westerkamp AC, Karimian N, Gouw AS, Bruinsma BG, Markmann JF, et al. Injury to peribiliary glands and vascular plexus before liver transplantation predicts formation of non-anastomotic biliary strictures. J Hepatol 2014;60:1172-9.

5. Meurisse N, Vanden Bussche S, Jochmans I, Francois J, Desschans B, Laleman W, et al. Outcomes of liver transplantations using donations after circulatory death: a single-center experience. Transplant Proc 2012;44:286873.

6. Laing RW, Scalera I, Isaac J, Mergental H, Mirza DF, Hodson J, et al. Liver transplantation using grafts from donors after circulatory death: A propensity score-matched study from a single center. Am J Transplant 2016;16:1795-804.

7. Lokmic Z, Musyoka J, Hewitson TD, Darby IA. Hypoxia and hypoxia signaling in tissue repair and fibrosis. Int Rev Cell Mol Biol 2012;296:139-85.

8. Peach CJ, Mignone VW, Arruda MA, Alcobia DC, Hill SJ, Kilpatrick LE, et al. Molecular pharmacology of VEGFA isoforms: Binding and signalling at VEGFR2. Int J Mol Sci 2018;19. pii: E1264. doi: 10.3390/ijms19041264.

9. Gaudio E, Barbaro B, Alvaro D, Glaser $\mathrm{S}$, Francis H, Ueno Y, et al. Vascular endothelial growth factor stimulates rat cholangiocyte proliferation via an autocrine mechanism. Gastroenterology 2006; 130:1270-82.

10. Hansen T, Hollemann D, Pitton MB, Heise M, Hoppe-Lotichius M, Schuchmann M, et al. Histological examination and evaluation of donor bile ducts received during orthotopic liver transplantation - a morphological clue to ischemic-type biliary lesion? Virchows Arch 2012;461:41-8.

11. Carpino G, Cardinale V, Folseraas T, Overi D, Floreani A, Franchitto A, et al.
Hepatic stem/progenitor cell activation differs between primary sclerosing and primary biliary cholangitis. Am J Pathol 2018;188:627-39.

12. Nobili V, Carpino G, De Peppo F, Caccamo R, Mosca A, Romito I, et al. Laparoscopic Sleeve gastrectomy improves nonalcoholic fatty liver disease-related liver damage in adolescents by reshaping cellular interactions and hepatic adipocytokine production. J Pediatr 2018;194:100-8 e3.

13. Carpino G, Cardinale V, Onori P, Franchitto A, Berloco PB, Rossi M, et al. Biliary tree stem/progenitor cells in glands of extrahepatic and intraheptic bile ducts: an anatomical in situ study yielding evidence of maturational lineages. J Anat 2012;220:186-99.

14. Carpino G, Cardinale V, Folseraas T, Overi D, Grzyb K, Costantini D, et al. Neoplastic transformation of the peribiliary stem cell niche in cholangiocarcinoma arisen in primary sclerosing cholangitis. Hepatology 2019;69:62238.

15. Overi D, Carpino G, Cardinale V, Franchitto A, Safarikia S, Onori P, et al. Contribution of resident stem cells to liver and biliary tree regeneration in human diseases. Int J Mol Sci 2018;19. pii: E2917. doi: 10.3390/ijms 19102917.

16. Nakanuma Y, Hoso M, Sanzen T, Sasaki M. Microstructure and development of the normal and pathologic biliary tract in humans, including blood supply. Microsc Res Tech 1997;38:552-70.

17. Roskams TA, Theise ND, Balabaud C, Bhagat G, Bhathal PS, Bioulac-Sage P, et al. Nomenclature of the finer branches of the biliary tree: canals, ductules, and ductular reactions in human livers. Hepatology 2004;39:1739-45.

18. Lanzoni G, Cardinale V, Carpino G. The hepatic, biliary, and pancreatic network of stem/progenitor cell niches in humans: A new reference frame for disease and regeneration. Hepatology 2016;64:277-86.

19. de Jong IEM, van Leeuwen OB, Lisman T, Gouw ASH, Porte RJ. Repopulating the biliary tree from the peribiliary glands. Biochim Biophys Acta Mol Basis Dis 2018;1864:1524-31.

20. Dipaola F, Shivakumar P, Pfister J, Walters S, Sabla G, Bezerra JA. Identification of intramural epithelial networks linked to peribiliary glands that express progenitor cell markers and proliferate after injury in mice. Hepatology 2013;58:1486-96.

21. Matsui S, Harada K, Miyata N, Okochi $\mathrm{H}$, Miyajima A, Tanaka M. Characterization of Peribiliary GlandConstituting Cells Based on Differential
Expression of Trophoblast Cell Surface Protein 2 in Biliary Tract. Am J Pathol 2018;188:2059-73.

22. Goossens N, Breguet R, De Vito C, Terraz S, Lin-Marq N, Giostra E, et al. Peribiliary gland dilatation in cirrhosis: relationship with liver failure and stem cell/proliferation markers. Dig Dis Sci 2017;62:699-707.

23. Nakanuma Y. A novel approach to biliary tract pathology based on similarities to pancreatic counterparts: is the biliary tract an incomplete pancreas? Pathol Int 2010;60:419-29.

24. Nakanuma Y, Harada K, Sasaki M, Sato Y. Proposal of a new disease concept "biliary diseases with pancreatic counterparts". Anatomical and pathological bases. Histol Histopathol 2014;29:1-10.

25. Nakagawa H, Suzuki N, Hirata Y, Hikiba Y, Hayakawa Y, Kinoshita H, et al. Biliary epithelial injury-induced regenerative response by IL-33 promotes cholangiocarcinogenesis from peribiliary glands. Proc Natl Acad Sci USA 2017;114:E3806-15.

26. Sutton ME, op den Dries S, Koster MH, Lisman T, Gouw AS, Porte RJ. Regeneration of human extrahepatic biliary epithelium: the peribiliary glands as progenitor cell compartment. Liver Int 2012;32:554-9.

27. van Rijn $R$, van Leeuwen $O B$, Matton APM, Burlage LC, Wiersema-Buist J, van den Heuvel MC, et al. Hypothermic oxygenated machine perfusion reduces bile duct reperfusion injury after transplantation of donation after circulatory death livers. Liver Transpl 2018;24: 655-64.

28. de Jong IEM, Matton APM, van Praagh JB, van Haaften WT, Wiersema-Buist J, van Wijk LA, et al. Peribiliary glands are key in regeneration of the human biliary epithelium after severe bile duct injury. Hepatology 2019;69:1719-34.

29. Furuyama K, Kawaguchi Y, Akiyama H, Horiguchi M, Kodama S, Kuhara T, et al. Continuous cell supply from a Sox9-expressing progenitor zone in adult liver, exocrine pancreas and intestine. Nat Genet 2011;43:34-41.

30. Vitale I, Manic G, De Maria R, Kroemer G, Galluzzi L. DNA damage in stem cells. Mol Cell 2017;66:306-19.

31. Glaser S, Mancinelli R, Onori P, Franchitto A, Ventet J, White M, et al. Ischemia reperfusion of the hepatic artery induces the functional damage of large bile ducts by changes in the expression of the cholangiocyte angiogenic factors, VEGF and angiopoietin. Gastroenterology 2011;140:S937.

32. Gaudio E, Barbaro B, Alvaro D, Glaser $\mathrm{S}$, Francis H, Franchitto A, et al. 
Administration of r-VEGF-A prevents hepatic artery ligation-induced bile duct damage in bile duct ligated rats. Am J Physiol Gastrointest Liver Physiol 2006;291:G307-17.

33. Fabris L, Cadamuro M, Fiorotto R, Roskams T, Spirli C, Melero S, et al. Effects of angiogenic factor overexpression by human and rodent cholangiocytes in polycystic liver diseases. Hepatology 2006;43:1001-12.

34. Fabris L, Cadamuro M, Libbrecht L, Raynaud P, Spirli C, Fiorotto R, et al.
Epithelial expression of angiogenic growth factors modulate arterial vasculogenesis in human liver development. Hepatology 2008;47:719-28.

35. Boulter L, Govaere O, Bird TG, Radulescu S, Ramachandran P, Pellicoro A, et al. Macrophage-derived Wnt opposes Notch signaling to specify hepatic progenitor cell fate in chronic liver disease. Nat Med 2012;18:572-9.

36. Franchitto A, Onori P, Renzi A, Carpino G, Mancinelli R, Alvaro D, et al. Expression of vascular endothelial growth factors and their receptors by hepatic progenitor cells in human liver diseases. Hepatobiliary Surg Nutr 2013;2:68-77.

37. Liu D, Li L, Zhang XX, Wan DY, Xi $\mathrm{BX}, \mathrm{Hu} \mathrm{Z}$, et al. SIX1 promotes tumor lymphangiogenesis by coordinating TGFbeta signals that increase expression of VEGF-C. Cancer Res 2014;74: 5597-607.

38. Weidemann A, Johnson RS. Biology of HIF-1alpha. Cell Death Differ 2008;15: 621-7. 